\title{
Pengaruh Desentralisasi Fiskal dan Investasi terhadap Pertumbuhan Ekonomi di Provinsi Jawa Tengah Tahun 2015-2019
}

\author{
Province Years 2015-2019) \\ Reni Anggita ${ }^{1 *}$, Liza Kurnia Sari² \\ 1,2Politeknik Statistika STIS \\ Jl. Otto Iskandardinata Nomor 64C, Jatinegara, Jakarta Timur \\ E-mail: ${ }^{1 * 2} 211709968 @$ stis.ac.id, ${ }^{2}$ lizakurnia@ stis.ac.id
}

(The Effect of Fiscal Decentralization and Investment on Economic Growth in Jawa Tengah

\begin{abstract}
ABSTRAK
Keberhasilan pembangunan untuk mengetahui maju tidaknya suatu wilayah dapat dilihat melalui pertumbuhan ekonomi. Hal yang menjadi perhatian adalah perekonomian Indonesia masih berpusat di Pulau Jawa, Jawa Tengah menjadi provinsi dengan pertumbuhan ekonomi terendah tahun 2015-2019. Namun, desentralisasi fiskal yang dilihat dari PAD dan dana perimbangan serta investasi yang dilihat dari PMDN dan PMA di Jawa Tengah berada di peringkat keempat dan bukan yang terbawah. Penelitian ini bertujuan untuk memberikan gambaran umum mengenai pertumbuhan ekonomi, PAD, dana perimbangan, PMDN, dan PMA. Metode analisis regresi data panel digunakan untuk mengetahui pengaruh PAD, dana perimbangan, PMDN, dan PMA terhadap pertumbuhan ekonomi di kabupaten/kota Provinsi Jawa Tengah tahun 20152019. Data yang digunakan pada penelitian ini bersumber dari BPS Provinsi Jawa Tengah. Model terbaik yang diperoleh adalah FEM SUR. Hasil penelitian ini mengindikasikan bahwa PAD, dana perimbangan, serta PMDN mempunyai pengaruh positif dan signifikan terhadap pertumbuhan ekonomi di Jawa Tengah tahun 2015-2019. Sedangkan, PMA tidak mempunyai pengaruh signifikan.
\end{abstract}

Kata kunci: pertumbuhan ekonomi, desentralisasi fiskal, investasi, FEM SUR

\begin{abstract}
The success of development to determine whether a region is progressing or not can be seen through economic growth. What is of concern is that the Indonesian economy is still centered on the island of Java, Jawa Tengah being the province with the lowest economic growth in 2015-2019. However, fiscal decentralization as seen from PAD and balancing funds and investment seen from PMDN and PMA in Central Java is ranked fourth and not the lowest. This research aims to provide an overview of economic growth, PAD, balancing funds, PMDN and PMA. Panel data regression analysis method was used to determine the effect of PAD, balancing funds, PMDN, and PMA on economic growth in districts/cities of Jawa Tengah Province in 2015-2019. The data used in this study were sourced from BPS Provinsi Jawa Tengah.. The best model obtained is FEM SUR. The results of this study indicate that PAD, balancing funds, and PMDN have a positive and significant effect on economic growth in Jawa Tengah in 2015-2019. Meanwhile, PMA hasn't significant effect.
\end{abstract}

Keywords: economic growth, fiscal decentralization, investment, FEM SUR

\section{PENDAHULUAN}

Pertumbuhan ekonomi dapat digunakan untuk menunjukkan keberhasilan pembangunan. Indikator ini menggambarkan sudah sampai mana aktivitas ekonomi suatu wilayah pada periode tertentu akan menghasilkan tambahan pendapatan masyarakat. Selain itu, menurut Sukirno (2005) meningkatkatnya buatan barang dan jasa yang diproduksi masyarakat berkaitan erat dengan pertumbuhan ekonomi. Bersumber dari Badan Pusat Statistik, pertumbuhan ekonomi nasional sebesar 5 persen di tahun 2019, mengalami penurunan dari tahun 2018 sebesar 0,32 persen. Andil paling besar terhadap PDRB di Indonesia pada tahun 2019 masih dipegang oleh Pulau Jawa yang menyumbang sebesar 59,03 persen.

Menurut Oates (1993), desentralisasi fiskal dapat menjadi rujukan penting dalam menaikkan pertumbuhan ekonomi lebih baik dan efisien di suatu wilayah. Dalam proses pembangunan ekonomi di suatu wilayah, Pendapatan Asli Daerah (PAD) sangat dibutuhkan untuk memenuhi anggaran belanja daerah. Berdasarkan UU Nomor 33 Tahun 2004 tentang Perimbangan Keuangan Antara Pemerintah Pusat dan Pemerintah Daerah menyebutkan bahwa PAD ialah satu dari beberapa sumber penerimaan daerah yang didapatkan dari retribusi daerah, pajak daerah, hasil pengelolaan kekayaan daerah yang dipisahkan, dan lainlain PAD yang sah. Selain itu, yang termasuk sumber penerimaan daerah adalah dana perimbangan. Investasi juga dapat menunjang kemajuan perekonomian suatu wilayah. Todaro (2003) menyebutkan bahwa kemajuan teknologi, pertumbuhan penduduk, serta akumulasi modal menjadi aspek komponen kunci pertumbuhan 
ekonomi suatu negara. Investasi baru ini akan memunculkan barang modal dan faktor produksi baru untuk menciptakan lapangan pekerjaan yang mendorong kegiatan ekonomi di suatu wilayah.

Selama tahun 2015-2019, Jawa Tengah menjadi provinsi yang paling rendah rata-rata pertumbuhan ekonominya di Pulau Jawa. Hal tersebut mengindikasikan bahwa usaha yang dilakukan untuk meningkatkan pertumbuhan ekonomi masih belum maksimal. Laju pertumbuhan PDRB Jawa Tengah mengalami fluktuatif pada tahun 2011-2019. Pertumbuhan ekonominya meningkat signifikan mulai tahun 2015. Lalu terjadi penurunan di tahun 2016 yang cukup signifikan pula yaitu sebesar 0,22 persen dari tahun 2015. Meskipun begitu, pertumbuhan ekonomi di Provinsi Jawa Tengah mulai stabil tahun 2017-2019. Dalam hal desentralisasi fiskal yang dilihat dari rata-rata realisasi nilai PAD dan dana perimbangan, Provinsi Jawa Tengah berada di peringkat keempat, dan bukan menjadi yang terendah di Pulau Jawa dalam kurun waktu 2015-2019. Sedangkan, pada rata-rata nilai realisasi investasi PMA dan PMDN, Jawa Tengah juga menduduki peringkat keempat di Pulau Jawa. Menariknya, Jawa Tengah menjadi satu-satunya provinsi di Pulau Jawa dengan investasi PMA selalu meningkat dari tahun 2015-2019. Dengan banyaknya potensi daerah yang dimiliki, seharusnya Jawa Tengah dapat memiliki penerimaan daerah yang tinggi dan berpotensi menjadi tempat yang strategis untuk berinvestasi, sehingga Provinsi Jawa Tengah tidak menjadi provinsi yang terbelakang pada kurun waktu tersebut karena memiliki pertumbuhan ekonomi terendah di Pulau Jawa.

RPJMD Jawa Tengah tahun 2018-2023 menyebutkan bahwa dalam mewujudkan visi dan misi pembangunannya, Jawa Tengah berdikari di bidang ekonomi yang ditunjukkan oleh pertumbuhan ekonominya harus memberikan pengaruh untuk menjadikan masyarakat Jawa Tengah lebih sejahtera dan hidup berkualitas secara berkelanjutan. Berlandaskan uraian latar belakang dan masalah yang disampaikan, tujuan dari penelitian ini ialah memberikan gambaran umum pertumbuhan ekonomi, desentralisasi fiskal yang dilihat dari dana perimbangan dan PAD, serta investasi yang dilihat dari PMDN dan PMA di kabupaten/kota Provinsi Jawa Tengah tahun 2015-2019. Selain itu, bertujuan untuk mengkaji pengaruh desentralisasi fiskal yang dilihat dari dana perimbangan dan PAD serta investasi yang dilihat dari PMDN dan PMA terhadap pertumbuhan ekonomi di kabupaten/kota Provinsi Jawa Tengah tahun 2015-2019. Unit analisis yang digunakan sebanyak 35 kabupaten/kota di Provinsi Jawa Tengah serta periode penelitian tahun 2015-2019, maka penelitian ini menggunakan analisis regresi data panel sebagai metode penelitian.

Beberapa penelitian terdahulu yang sejalan dengan penelitian ini, seperti yang dilakukan Irvan (2016). Penelitian tersebut memiliki tujuan untuk mengkaji dampak dana perimbangan dan PAD terhadap pertumbuhan ekonomi dengan variabel intervening belanja modal. Analisis jalur (path analysis) menjadi metode analisis yang digunakan dalam studi tersebut sehingga didapatkan kesimpulan bahwa dana perimbangan dan PAD berpengaruh signifikan dan positif terhadap pertumbuhan ekonomi dan belanja modal. Penelitian selanjutnya dilakukan oleh Rofii (2017) yang bertujuan menganalisis pengaruh tenaga kerja, PMA, dan inflasi terhadap pertumbuhan ekonomi di Jawa Timur dengan menggunakan metode analisis regresi linier berganda dan diperoleh kesimpulan bahwa hanya variabel tenaga kerja yang mempunyai pengaruh positif terhadap pertumbuhan ekonomi secara signifikan, sedangkan variabel inflasi mempunyai pengaruh yang negatif serta signifikan dan PMA tidak berpengaruh signifikan dan bertanda negatif. Lain halnya dengan penelitian Rizky (2016) dengan fokus penelitiannya adalah provinsi-provinsi Indonesia tahun 2010-2013. Dalam penelitian tersebut, ditemukan bahwa variabel yang dapat meningkatkan pertumbuhan ekonomi adalah PMA, PMDN, serta belanja modal.

Berdasarkan permasalahan yang telah dipaparkan, maka diperoleh rumusan hipotesis penelitian sebagai berikut:

1. PAD mempunyai pengaruh positif serta signifikan terhadap pertumbuhan ekonomi kabupaten/kota di Jawa Tengah tahun 2015-2019.

2. Dana Perimbangan mempunyai pengaruh positif dan signifikan terhadap pertumbuhan ekonomi kabupaten/kota di Jawa Tengah tahun 2015-2019.

3. PMDN mempunyai pengaruh positif serta signifikan terhadap pertumbuhan ekonomi kabupaten/kota di Jawa Tengah tahun 2015-2019.

4. PMA mempunyai pengaruh positif dan signifikan terhadap pertumbuhan ekonomi kabupaten/kota di Jawa Tengah tahun 2015-2019.

\section{METODE}

\section{Landasan Teori}

Pertumbuhan Ekonomi

Todaro (2003) menyebutkan bahwa pembangunan ekonomi ialah suatu sistem multidimensi yang menekankan bermacam transformasi dari aspek-aspek fundamental tersebut untuk mencapai beberapa 
indikatornya seperti pengentasan kemiskinan, penyelesaian ketimpangan pendapatan, dan peningkatan pertumbuhan ekonomi. Pertumbuhan ekonomi dapat dipicu oleh beberapa hal, seperti kenaikan Produk Domestik Bruto (PDB) yang tidak dipengaruhi oleh pertumbuhan penduduk serta ada tidaknya perubahan struktur perekonomian (Arsyad, 2015).

Teori Pertumbuhan Ekonomi Harrod-Domar

Teori ini menganalisis syarat yang dibutuhkan untuk tumbuh dan berkembangnya perekonomian dalam jangka panjang/kondisi dinamis (Arsyad, 2015).

Teori Pertumbuhan Ekonomi Neo Klasik (Solow-Swan)

Teori ini menyebutkan bahwa penambahan pengadaan faktor-faktor produksi seperti kemajuan teknologi, tenaga kerja, akumulasi modal, dan penduduk akan mendorong pertumbuhan ekonomi (Arsyad, 2015).

Desentralisasi Fiskal

Desentralisasi fiskal merupakan pelimpahan kekuasaan dari pemerintah pusat ke pemerintah daerah dalam menata dan mengurus sendiri wilayahnya. Oates (1993) menyebutkan bahwa desentralisasi fiskal sanggup meningkatkan pertumbuhan ekonomi karena menjadi lebih efisien di mana pemerintah daerah lebih memahami keperluan dan keterbatasan anggaran di daerahnya sendiri sehingga pembuatan rancangan pembelanjaan lebih terarah. Sesuai dengan UU Nomor 33 Tahun 2004 tentang Perimbangan Keuangan antara Pemerintah Pusat dan Pemerintah Daerah, dalam pelaksanaan desentralisasi, pendapatan daerah berasal dari PAD, dana perimbangan, dan lain-lain pendapatan yang sah.

Investasi

Sukirno (2005) menyatakan bahwa investasi merupakan pengeluaran dari para penanam modal ataupun perusahaan yang digunakan untuk menghasilkan barang modal serta perlengkapan produksi, sehingga dapat meningkatkan produktivitas barang dan jasa dalam perekonomian. Pada teori pertumbuhan ekonomi HarrodDomar, investasi sebagai pengeluaran dapat meningkatkan kemampuan dalam memproduksi barang dan jasa maupun permintaan efektif masyarakat dalam perekonomian. Peningkatan kemampuan memproduksi ini tidak serta merta secara langsung menciptakan peningkatan pendapatan nasional dan produksi tetapi perlu diikuti oleh pertambahan pengeluaran masyarakat. Maka dari itu, pertumbuhan ekonomi tercipta apabila kapasitas memproduksi bertambah, pendapatan nasional bertambah, dan pengeluaran masyarakat mengalami kenaikan dari periode sebelumnya (Sukirno, 2005). Berdasarkan UU No. 25 Tahun 2007 tentang Penanaman Modal, terdapat dua status pemodalan yaitu Penanaman Modal Dalam Negeri (PMDN) dan Penanaman Modal Asing (PMA).

\section{Cakupan Penelitian}

Penelitian ini mencakup data cross section dan time series yaitu sebanyak 35 kabupaten/kota di Provinsi Jawa Tengah dalam kurun waktu 5 tahun yaitu tahun 2015-2019. Variabel dependen yang digunakan adalah Produk Domestik Regional Bruto Atas Dasar Harga Konstan tahun dasar 2010 (PDRB ADHK). Variabel independen yang digunakan adalah Penanaman Modal Asing (PMA), Penanaman Modal Dalam Negeri (PMDN), dana perimbangan, dan Pendapatan Asli Daerah (PAD). Digunakan data sekunder yang bersumber dari Badan Pusat Statistik (BPS) Provinsi Jawa Tengah.

\section{Metode Analisis}

Metode analisis yang digunakan terdiri dari analisis deskriptif dan inferensia. Analisis deskriptif akan menggambarkan secara umum mengenai keadaan dana perimbangan, PAD, PMA, PMDN, serta pertumbuhan ekonomi kabupaten/kota di Provinsi Jawa Tengah periode 2015-2019 dengan menggunakan visualisasi grafik dan boxplot. Sedangkan analisis inferensia digunakan untuk menganalisis pengaruh investasi dan desentralisasi fiskal terhadap pertumbuhan ekonomi di kabupaten/kota Provinsi Jawa Tengah periode 20152019 menggunakan analisis regresi data panel.

Adapun tahapan-tahapan analisis regresi data panel yang diterapkan adalah sebagai berikut:

1. Pemilihan model regresi data panel dengan menggunakan 3 pengujian yaitu:

Pada tahapan awal analisis regresi data panel, maka perlu dilakukan pembentukan model yang terdiri dari beberapa kemungkinan yaitu Random Effect Model (REM), Common Effect Model (CEM), serta Fixed Effect Model (FEM). Agar dapat menentukan model terbaik, maka dilakukan 3 pengujian yaitu:

- Uji Chow, untuk menentukan model terbaik antara FEM dan CEM. Jika terpilih CEM, maka dilanjutkan uji BP-LM dan jika terpilih FEM, maka dilanjutkan uji hausman.

- Uji Hausman, untuk menentukan model terbaik antara FEM dan REM. 
- $\quad$ Uji Breusch Pagan Lagrange Multiplier (BP-LM), untuk menentukan model terbaik antara REM dan CEM.

Secara umum, model regresi data panel pada penelitian ini ialah sebagai berikut:

$\ln \left(\mathrm{PDRB}_{\mathrm{it}}\right)=\alpha+\beta_{1} \ln \left(\mathrm{PAD}_{\mathrm{it}}\right)+\beta_{2} \ln \left(\right.$ Perimbangan $\left._{\mathrm{it}}\right)+\beta_{3} \ln \left(\mathrm{PMDN}_{\mathrm{it}}\right)+\beta_{4} \ln \left(\mathrm{PMA}_{\mathrm{it}}\right)+\mathrm{u}_{\mathrm{it}} \ldots \ldots . .(1)$

Keterangan:

$\ln \left(\mathrm{PDRB}_{\mathrm{it}}\right) \quad=$ logaritma natural PDRB ADHK kabupaten/kota $\mathrm{i}$ tahun $\mathrm{t}$

$\alpha \quad=$ koefisien intersep

$\beta_{1}, \beta_{2}, \beta_{3}, \beta_{4} \quad=$ koefisien regresi variabel independen

$\ln \left(\right.$ Perimbangan $\left._{\mathrm{it}}\right)=$ logaritma natural realisasi PAD kabupaten/kota $\mathrm{i}$ tahun $\mathrm{t}$

$\ln \left(\mathrm{PMDN}_{\mathrm{it}}\right) \quad=$ logaritma natural realisasi PMDN kabupaten/kota $\mathrm{i}$ tahun $\mathrm{t}$

$\ln \left(\mathrm{PMA}_{\mathrm{it}}\right) \quad=$ logaritma natural realisasi PMA kabupaten/kota i tahun $\mathrm{t}$

$\mathrm{u}_{\mathrm{it}}$

$=$ komponen error model

2. Uji struktur matriks varians-kovarian residual, dilakukan dengan 2 pengujian, yaitu:

- Uji LM, digunakan untuk mengetahui struktur matriks varians kovarian residual bersifat homoskedastisitas atau heteroskedastisitas. Apabila hasil uji didapatkan bahwa strukturnya bersifat homoskedastisitas, maka estimasi parameter menggunakan OLS. Sedangkan jika hasil uji didapatkan adalah heteroskedastisitas, maka dilanjutkan uji $\lambda \mathrm{LM}$ untuk menentukan estimasi yang digunakan.

- Uji $\lambda \mathrm{LM}$, digunakan untuk mengetahui struktur matriks varians kovarian residual terdapat cross sectional correlation atau tidak. Jika hasil pengujian didapatkan tidak terdapat cross sectional correlation, maka GLS digunakan sebagai estimasi, tetapi jika hasil pengujian menunjukkan sebaliknya, maka estimasi parameter yang digunakan adalah FGLS/SUR (Seemingly Unrelated Regression).

3. Uji asumsi klasik

Menurut Gujarati (2008), jika GLS dan FGLS yang terpilih sebagai metode estimasi, maka uji asumsi yang diperlukan cukup asumsi normalitas dan nonmultikolinearitas. Uji normalitas dilakukan dengan uji JarqueBera dan uji asumsi nonmultikolinearitas diidentifikasi melalui nilai VIF (Variance Inflation Factor).

4. Pengujian keberartian model

- Uji F, dilakukan untuk menguji signifikansi parameter secara simultan.

- Uji t, dilakukan untuk menguji signifikansi parameter secara parsial.

- $\quad R$-squared, untuk mengetahui besarnya pengaruh variabel independen terhadap variabel dependen.

5. Interpretasi model

\section{HASIL DAN PEMBAHASAN}

\section{Gambaran Pertumbuhan Ekonomi, Desentralisasi Fiskal, dan Investasi di Kabupaten/Kota Provinsi Jawa Tengah Tahun 2015-2019}

\section{Gambaran Pertumbuhan Ekonomi}

Berdasarkan Gambar 1, menunjukkan tren PDRB ADHK tahun dasar 2010 di kabupaten/kota Provinsi Jawa Tengah yang meningkat selama lima tahun. Pada 2015, rata-rata PDRB sebesar 23 triliun rupiah, lalu meningkat di tahun 2016 menjadi 24,26 triliun rupiah, dan selalu meningkat setiap tahunnya hingga pada tahun 2019 memiliki rata-rata PDRB sebesar 28,3 triliun rupiah. Kota Semarang merupakan wilayah di Jawa Tengah yang memiliki PDRB tertinggi dibandingkan dengan kabupaten/kota lainnya. Pada tahun 2015, PDRB Kota Semarang mencapai 109,11 triliun rupiah dan semakin bertambah menjadi 140,33 triliun rupiah pada tahun 2019. Tingginya PDRB Kota Semarang yang jauh dari kabupaten/kota lainnya dikarenakan Semarang merupakan ibu kota Provinsi Jawa Tengah. Tempatnya yang berada di tengah-tengah menyebabkan wilayah yang kondusif dan memiliki potensi ekonomi di wilayah tersebut. Selain itu, sebagai wilayah yang merupakan ibu kota provinsi, Kota Semarang memiliki kelebihan seperti mudah dijangkau serta adanya jaminan administrasi. Dari adanya jaminan administrasi inilah yang mendukung investasi mudah masuk ke Kota Semarang sehingga menyebabkan pertumbuhan ekonomi meningkat. Selain itu, terdapat dua wilayah dengan PDRB tertinggi di bawah Kota Semarang yaitu Kabupaten Cilacap dan Kabupaten Kudus. 


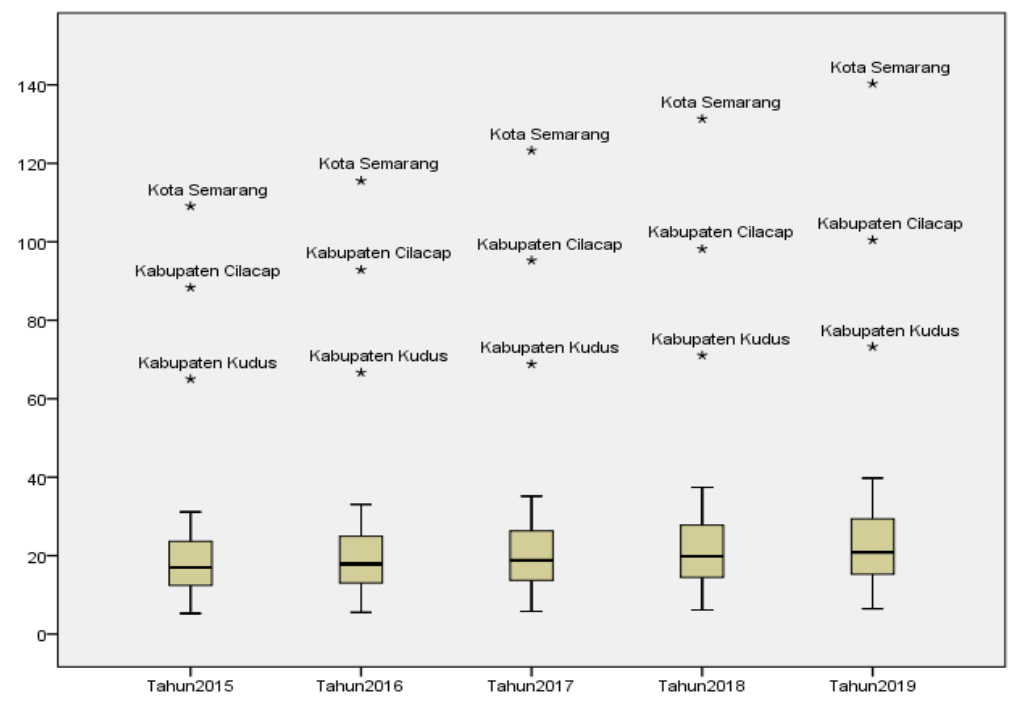

Sumber: BPS, diolah

Gambar 1. PDRB ADHK tahun dasar 2010 Provinsi Jawa Tengah tahun 2015-2019 (triliun rupiah).

\section{Gambaran Desentralisasi Fiskal}

Gambar 2 menunjukkan bahwa PAD di Jawa Tengah tahun 2015-2019 rata-rata tidak selalu mengalami peningkatan. Terdapat peningkatan perolehan PAD di tahun 2016, 2017, dan 2019, sedangkan pada tahun 2018 terjadi penurunan. Peningkatan PAD ini menunjukkan bahwa setiap wilayah mampu menggali dan mengembangkan potensi wilayahnya masing-masing yang didukung pula pada sumber-sumber penerimaan daerah yang semakin baik. Perolehan PAD tertinggi berada pada Kota Semarang, sejalan dengan perolehan PDRB, Kota Semarang juga menjadi daerah dengan PDRB tertinggi di Jawa Tengah, hal ini menunjukkan bahwa tingginya PAD sejalan dengan tingginya pertumbuhan ekonomi yang diukur dari PDRB.

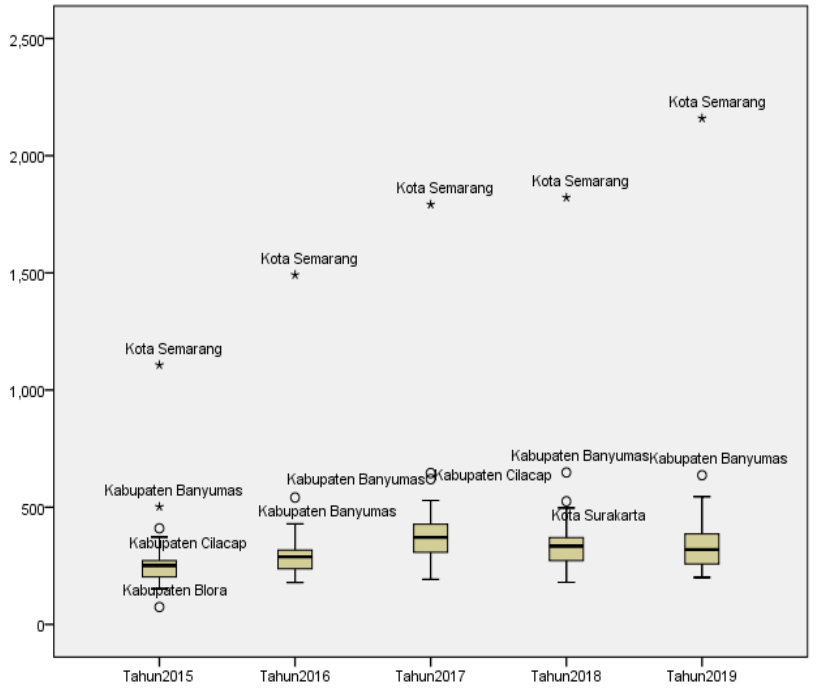

Sumber : BPS, diolah

Gambar 2. PAD Kabupaten/Kota Provinsi Jawa Tengah Tahun 2015-2019 (Miliar Rupiah).

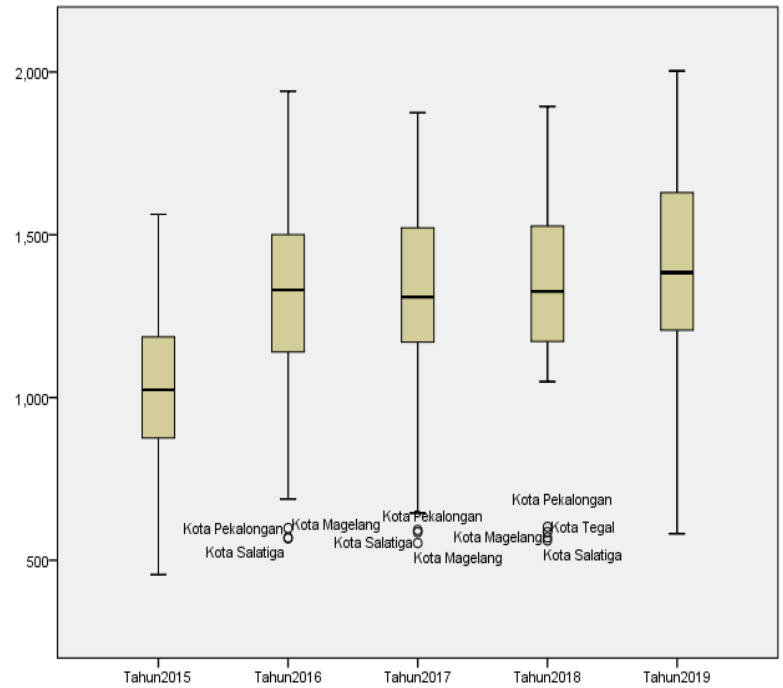

Sumber : BPS, diolah

Gambar 3. Dana Perimbangan Kabupaten/Kota Provinsi Jawa Tengah Tahun 20152019 (Miliar Rupiah).

Berdasarkan Gambar 3, secara umum dana perimbangan kabupaten/kota di Provinsi Jawa Tengah memiliki tren naik di setiap tahunnya mulai dari tahun 2015-2019. Rata-rata dana perimbangan tahun 2015 adalah sebesar 1014,7 miliar rupiah, naik menjadi 1296,43 miliar rupiah tahun 2016, dan mengalami sedikit penurunan di angka 1293,19 miliar rupiah di tahun 2017. Selanjutnya bertambah kembali menjadi 1307,93 miliar rupiah pada tahun 2018 lalu 1371,47 miliar rupiah pada tahun 2019. Dengan adanya peningkatan dana 
perimbangan ini menunjukkan bahwa ketimpangan fiskal antar-pemerintah daerah, serta antara pemerintah dan pemerintah daerah semakin berkurang.

\section{Gambaran Investasi}

Berdasarkan Gambar 4 menunjukkan bahwa tiga besar kabupaten/kota dengan total PMDN terbesar di Jawa Tengah tahun 2015-2019 adalah Kabupaten Cilacap, Kota Magelang, dan Kota Semarang. Kabupaten Cilacap memiliki nilai investasi PMDN tertinggi di Jawa Tengah yaitu dengan perolehan total sebesar 28,33 triliun rupiah. Wilayahnya yang strategis dengan beragam potensi investasi yang dimiliki, tidak heran bahwa Kabupaten Cilacap merupakan kabupaten dengan nilai PMDN tertinggi di Jawa Tengah. Adapun dua wilayah lain yang memiliki nilai investasi PMDN tertinggi setelah Kabupaten Cilacap adalah Kota Magelang dan Kota Semarang. Sejalan dengan PDRB yang didapatkan, Kabupaten Cilacap dan Kota Semarang menduduki wilayah tiga besar dengan perolehan PDRB tertinggi pula. Hasil ini mengindikasikan bahwa investasi dapat menumbuhkan pertumbuhan ekonomi

Total PMDN Kabupaten/Kota di Provinsi Jawa Tengah Tahun 2015-2019

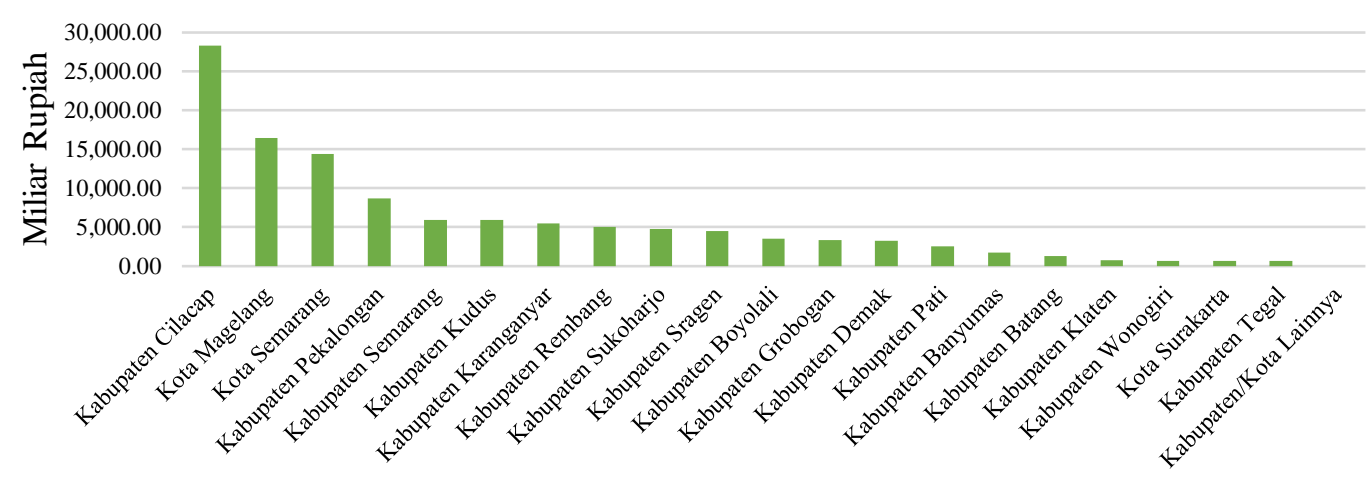

Kabupaten/Kota

Sumber : BPS, diolah

Gambar 4. Total PMDN di Kabupaten/Kota Provinsi Jawa Tengah Tahun 2015-2019.

Selain PMDN, investasi PMA juga diperlukan untuk mendukung kegiatan perekonomian suatu wilayah dalam mendorong pertumbuhan ekonomi. Pada Gambar 5 menunjukkan bahwa total realisasi nilai PMA di kabupaten/kota Provinsi Jawa Tengah tahun 2015-2019 terbesar berada di Kabupaten Jepara. Total nilai PMA di Kabupaten Jepara sebesar 3,55 miliar US\$. Selanjutnya di urutan kedua adalah Kabupaten Batang dan disusul Kota Semarang di urutan ketiga dengan nilai investasi PMA-nya secara berturut-turut adalah sebesar 2,85 miliar US\$ dan 784 juta US\$. Ketiga wilayah kabupaten/kota tersebut menjadi favorit PMA di Jawa Tengah.

Total PMA Kabupaten/Kota di Provinsi Jawa Tengah Tahun 2015-2019

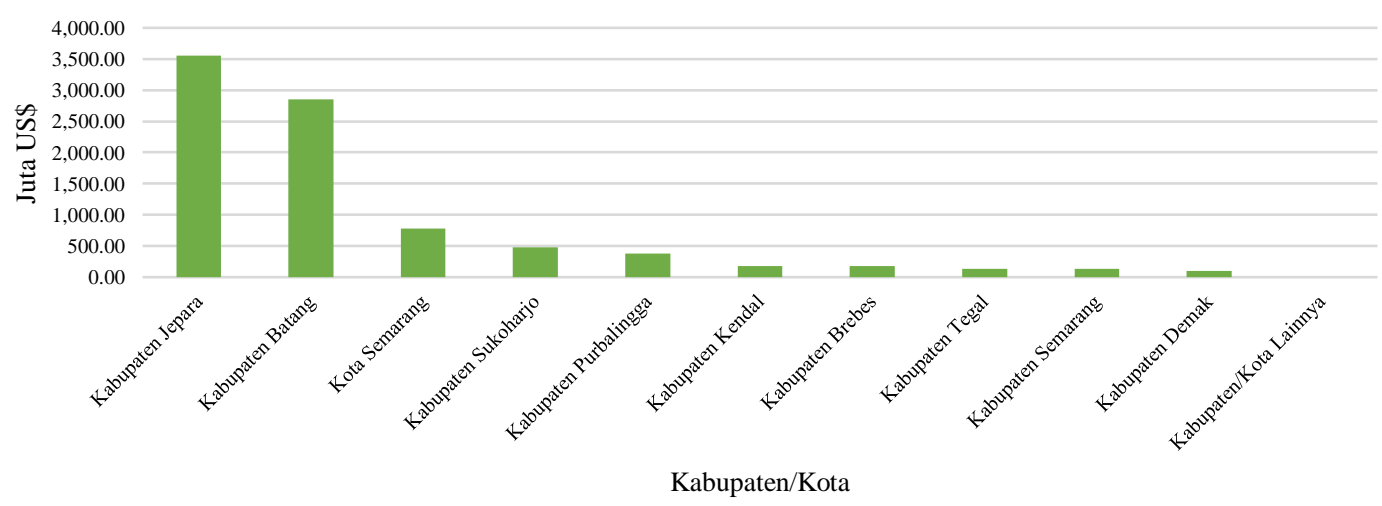

Sumber : BPS, diolah

Gambar 5. Total PMA di Kabupaten/Kota Provinsi Jawa Tengah Tahun 2015-2019 


\section{Pengaruh Variabel Desentralisasi Fiskal dan Investasi Terhadap Pertumbuhan Ekonomi di Kabupaten/Kota Provinsi Jawa Tengah Tahun 2015-2019}

\section{Pemilihan Model Terbaik}

Pada tahap pertama, dilakukan pengujian untuk mendapatkan model terbaik. Hasil Uji Chow pada Lampiran 1 menunjukkan keputusan bahwa FEM lebih baik dibandingkan CEM. Setelah Uji Chow mendapatkan hasil model fixed effect, maka dilanjutkan uji Hausman untuk menentukan model antara FEM dan REM. Hasil yang didapat pada Lampiran 2 menyatakan bahwa FEM lebih baik daripada REM. Maka dari itu, FEM merupakan model terbaik yang terpilih.

\section{Pemilihan Estimator}

Selanjutnya akan dilakukan uji asumsi homoskedastisitas dengan menggunakan pengujian struktur matriks varians kovarian residual dari model. Berdasarkan output pada Lampiran 3, didapatkan hasil tolak $\mathrm{H}_{0}$ pada tingkat signifikansi 5\% memiliki arti bahwa struktur matriks varians-kovarian residual bersifat heteroskedastisitas. Dilanjutkan uji $\lambda \mathrm{LM}$ untuk mengetahui apakah terdapat korelasi antar individu atau tidak, uji ini juga bisa disebut dengan uji cross correlation. Berdasarkan Lampiran 4 yang merupakan output dari uji $\lambda \mathrm{LM}$, menunjukkan bahwa didapatkan hasil tolak $\mathrm{H}_{0}$, yang berarti terdapat korelasi antarresidual individu. Berdasarkan hasil tersebut, disimpulkan bahwa data bersifat heteroskedastis dengan adanya cross sectional correlation, sehingga metode estimasi yang paling tepat digunakan ialah FEM with cross section Seemingly Unrelated Regression (SUR).

\section{Uji Asumsi Klasik}

Tahapan berikutnya adalah pengujian asumsi klasik dari model. Pada tahap sebelumnya telah ditentukan yang terpilih sebagai model terbaik adalah FEM dengan penimbang SUR, maka dari itu hanya diperlukan uji asumsi normalitas dan nonmultikolinieritas. Uji asumsi normalitas pada Lampiran 5, digunakan uji JarqueBera yang memperlihatkan bahwa nilai JB sebesar 5,6897 dengan p-value sebesar 0,0581, maka residual berdistribusi normal. Selanjutnya pengujian multikolinieritas bisa dilihat dengan nilai VIF pada Lampiran 6, terlihat bahwa nilai VIF pada semua variabel independen berada di bawah angka 10, maka tidak terjadi multikolinieritas.

\section{Variabel-Variabel yang Memengaruhi Pertumbuhan Ekonomi}

Berdasarkan hasil tahapan pengujian, diperoleh model terbaik yaitu FEM dengan metode estimasi SUR dengan output pada Tabel 1. Berdasarkan output, pada uji F didapatkan hasil bahwa terdapat minimal satu variabel independen yang memengaruhi variabel pertumbuhan ekonomi secara signifikan. Selanjutnya adalah melakukan uji t untuk melihat pengaruh dari variabel independen terhadap variabel pertumbuhan ekonomi secara parsial. Pada output hasil analisis, menyatakan bahwa PAD, dana perimbangan, dan PMDN memiliki pengaruh positif dan signifikan terhadap pertumbuhan ekonomi. Sedangkan, variabel PMA tidak mempunyai pengaruh signifikan dan bertanda negatif terhadap pertumbuhan ekonomi. Pada output hasil pengolahan, didapatkan nilai $R^{2}$ adjusted sebesar 0,9988. Nilai ini menjelaskan bahwa variasi dari variabel dependen yang mampu dijelaskan oleh variabel independen ialah sebesar 99,88 persen, sedangkan sebesar 0,12 persen sisanya dijelaskan oleh variabel lain selain yang ada dalam model.

Tabel 1. Hasil Output FEM SUR

\begin{tabular}{ccccc}
\hline Variabel & Koefisien & Standar Error & t-Statistic & Prob. \\
\hline C & 1,7721 & 1,5490 & 1,1441 & 0,2546 \\
Ln(PAD) & 0,2303 & 0,0407 & 5,6547 & $0,0000^{*}$ \\
Ln(Perimbangan) & 0,4941 & 0,0681 & 7,2538 & $0,0000^{*}$ \\
Ln(PMDN) & 0,0019 & 0,0008 & 2,4931 & $0,0139^{*}$ \\
Ln(PMA) & $-0,0011$ & 0,0010 & $-1,0737$ & 0,2851 \\
Adj. R-squared & 0,9988 & & & \\
F-statistic & 3950,144 & & & \\
Prob(F-statistic) & 0,0000 & & & \\
\hline
\end{tabular}

Berdasarkan hasil pengujian di atas, model regresi data panel terbaik untuk mengkaji pengaruh desentralisasi fiskal dan investasi terhadap pertumbuhan ekonomi di kabupaten/kota Provinsi Jawa Tengah adalah melalui pendekatan model fixed effect dengan penimbang SUR. Persamaan model yang didapatkan adalah sebagai berikut:

$$
\begin{aligned}
\ln \left(\widehat{P D R B}_{i t}\right)= & \left(1,7721+\mu_{i}\right)+0,2303 \ln \left(P A D_{i t}\right)^{*}+0,4941 \ln \left(P E R I M B A N G A N_{i t}\right)^{*}+ \\
& 0,0019 \ln \left(P M D N_{i t}\right)^{*}-0,0011 \ln \left(P M A_{i t}\right)
\end{aligned}
$$

Keterangan : *) Signifikan pada tingkat signifikansi 5\% 


\section{Interpretasi Efek Individu Model FEM}

Model terbaik dengan menggunakan estimasi fixed effect SUR memberikan efek individu. Pada Lampiran 7, didapatkan nilai efek individu terbesar adalah Kota Semarang dengan nilai 1,3954. Nilai ini memiliki arti bahwa pertumbuhan ekonomi Kota Semarang merupakan paling tinggi di Jawa Tengah jika bergantung dari efek individunya sebesar 1,3954 dengan asumsi variabel independen pada persamaan tidak berubah. Efek individu mencerminkan faktor-faktor yang tidak tercakup, sehingga dapat dianalisis dengan menjelaskan aspek-aspek lain di luar model namun masih mempunyai hubungan atas variabel independen dalam model. Beberapa faktor tersebut seperti, Kota Semarang merupakan daerah yang strategis yang merupakan ibukota dari Provinsi Jawa Tengah. Selain itu, banyak industri yang berdiri untuk menunjang kegiatan perekonomiannya.

\section{Interpretasi Hasil Model Terbaik}

Berdasarkan hasil penelitian, PAD memiliki pengaruh signifikan dan bertanda positif terhadap PDRB. Didapatkan nilai koefisien slope regresinya yaitu sebesar 0,2303, menggambarkan elastisitas PDRB terhadap PAD memiliki besaran yang positif sebesar 0,2303. Mempunyai makna bahwa saat kenaikan PAD sebesar satu persen maka menyebabkan kenaikan PDRB kabupaten/kota di Jawa Tengah sebesar 0,2303 persen dengan asumsi variabel lain konstan (ceteris paribus). Hal tersebut sejalan dengan hipotesis sebelumnya dan selaras dengan penelitian yang diteliti oleh Irvan (2016) menunjukkan bahwa PAD memiliki pengaruh positif dan signifikan terhadap pertumbuhan ekonomi. Meningkatnya PAD berdampak pula pada peningkatan aktivitas perekonomian di berbagai sektor, misalnya sektor industri, jasa, perdagangan, dan sektor-sektor lainnya. Dengan begitu, daerah akan lebih leluasa dalam merencanakan dan menyusun kegiatan maupun yang berkaitan dengan pengeluaran, yang nantinya akan memberikan dampak langsung terhadap pembangunan daerahnya, misalnya saja dari segi infrastruktur. Daerah dengan pendapatan yang tinggi akan memberikan dampak pada pembangunan dan perkembangan daerahnya yang diwujudkan dalam infrastruktur, sarana prasarana, dan fasilitas untuk kepentingan publik. Dengan begitu, terwujudnya peningkatan kemampuan daerah dalam melayani kebutuhan masyarakat sehingga pertumbuhan ekonomi daerah tersebut dapat meningkat.

Dana perimbangan memiliki pengaruh signifikan dan bertanda positif terhadap PDRB. Didapatkan nilai koefisien slope regresinya adalah 0,4941, menggambarkan bahwa elastisitas PDRB terhadap dana perimbangan memiliki besaran yang positif yaitu sebesar 0,4941. Memiliki makna bahwa setiap kenaikan dana perimbangan sebesar satu persen maka akan menaikkan PDRB kabupaten/kota di Jawa Tengah sebesar 0,4941 persen dengan asumsi variabel lain konstan. Hal tersebut cocok dengan hipotesis sebelumnya dan selaras dengan penelitian Irvan (2016) yang menunjukkan bahwa dana perimbangan mempunyai signifikan dan positif terhadap pertumbuhan ekonomi. Adanya dana perimbangan yang merupakan dana transfer dari pemerintah pusat ke pemerintah daerah memiliki tujuan untuk menekan ketidakseimbangan fiskal antar-pemerintah daerah serta antara pemerintah dan pemerintah daerah. Besar kecilnya dana perimbangan yang didapatkan suatu wilayah, akan memengaruhi pula rendah tingginya pertumbuhan ekonomi di wilayah tersebut. Peningkatan dana perimbangan yang berdampak pula pada peningkatan pertumbuhan ekonomi mengindikasikan bahwa daerah mampu mengalokasikan dana yang telah diterima dengan baik untuk pembangunan dan menyejahterakan masyarakat.

Selanjutnya adalah PMDN mempunyai pengaruh positif dan signifikan terhadap PDRB. Hasil output memperlihatkan bahwa nilai koefisien slope regresinya, yang menggambarkan elastisitas PDRB terhadap PMDN, memiliki besaran yang positif yaitu sebesar 0,0019. Memiliki arti bahwa setiap kenaikan PMDN sebesar satu persen maka akan menambah PDRB sebesar 0,0019 persen dengan asumsi variabel lain konstan. Temuan ini sesuai dengan hipotesis sebelumnya dan selaras dengan penelitian Rizky (2016) yang menunjukkan hasil bahwa PMDN berpengaruh signifikan dan bertanda positif terhadap pertumbuhan ekonomi provinsi di Indonesia dari tahun 2010-2013. Investasi merupakan salah satu kunci untuk mendorong pembangunan terutama di negara berkembang, terutama dalam hal pertumbuhan ekonomi. Investasi sebagai pengeluaran dapat meningkatkan kemampuan untuk menghasilkan barang dan jasa maupun permintaan efektif masyarakat dalam perekonomian. Masalah kekurangan modal dapat teratasi dengan adanya investasi PMDN di Jawa Tengah dan peningkatan PMDN di Jawa Tengah akan meningkatkan proses pertumbuhan ekonomi Jawa Tengah.

PMA tidak memiliki pengaruh signifikan dan bertanda negatif terhadap PDRB. Hasil pengujian ini tidak sejalan dengan hipotesis sebelumnya tetapi sejalan dengan penelitian Rofii (2017) yang memperlihatkan bahwa PMA tidak memiliki pengaruh signifikan dan bertanda negatif terhadap pertumbuhan ekonomi. Penyebabnya dapat dikarenakan pemerintah daerah kurang optimal dalam mengupayakan peluang investasi untuk menarik investor asing menanamkan modalnya di Jawa Tengah. Terlebih hanya sedikit wilayah saja yang dilirik investor asing sebagai daerah yang diminati untuk menanam modalnya. Selain itu, adanya 
beberapa kebijakan-kebijakan yang kurang sesuai untuk menunjang perkembangan investasi yang akhirnya membuat kurangnya minat para investor asing untuk berinvestasi di Jawa Tengah.

\section{KESIMPULAN}

Kesimpulan yang dapat ditarik berdasarkan hasil pembahasan sebelumnya adalah yang pertama, pertumbuhan ekonomi Provinsi Jawa Tengah tahun 2015-2019 secara umum memiliki tren meningkat, dengan PDRB ADHK tahun dasar 2010 yang selalu mengalami kenaikan pada tahun 2015-2019 di setiap kabupaten/kota. Dari variabel desentralisasi fiskal, memiliki tren meningkat selama tahun 2015-2019. Sedangkan, dari sisi investasi, realisasi nilai PMDN paling tinggi berada di Kabupaten Cilacap dan realisasi nilai PMA tertinggi berada di Kabupaten Jepara. Kedua, variabel PAD, dana perimbangan, dan PMDN mempunyai pengaruh positif dan signifikan terhadap PDRB kabupaten/kota di Jawa Tengah tahun 2015-2019. Namun, PMA tidak berpengaruh signifikan dan bertanda negatif terhadap PDRB kabupaten/kota di Jawa Tengah tahun 2015-2019.

Adapun saran yang dapat diberikan adalah adanya indikasi ketidakmerataan PAD yang didapatkan oleh kabupaten/kota, pemerintah kabupaten/kota harus mengupayakan potensi apa yang dimiliki daerahnya untuk menambah PAD, upaya tersebut dapat melalui pajak atau retribusi daerah. Sedangkan dari segi investasi, pemerintah daerah bersama-sama dengan lembaga atau instansi, baik pemerintah ataupun swasta, harus lebih mengoptimalkan faktor pendorong berinvestasi, baik dalam pengorganisasian promosi dan pelayanan penanaman modal maupun dalam pengembangan peluang potensi daerah.

\section{DAFTAR PUSTAKA}

Arsyad, Lincolin. (2015). Pembangunan Ekonomi Edisi Kelima. Jakarta: UPP STIM YKPN.

Badan Pusat Statistik. (2018). Statistik Keuangan Pemerintah Provinsi 2015-2018. Jakarta: BPS.

Badan Pusat Statistik. (2019). Statistik Keuangan Pemerintah Provinsi 2016-2019. Jakarta: BPS.

Badan Pusat Statistik (2020). Laju Pertumbuhan PDRB Atas Dasar Harga Konstan 2015-2019. Jakarta: BPS.

Badan Pusat Statistik. (2020). Realisasi Investasi Penanaman Modal Dalam Negeri Menurut Provinsi 20152019. Jakarta: BPS.

Badan Pusat Statistik. (2020). Realisasi Investasi Penanaman Modal Luar Negeri Menurut Provinsi 20152019. Jakarta: BPS.

Badan Pusat Statistik Jawa Tengah. (2020). Laju Pertumbuhan PDRB Jawa Tengah Atas Dasar Harga Konstan 2015-2019. Semarang: BPS Provinsi Jawa Tengah.

Bappeda. (2019). Rencana Pembangunan Jangka Menengah Daerah 2018-2023. Bappeda : Jawa Tengah.

Gujarati, Damodar. (2008). Basic Econometric (5 ${ }^{\text {th }}$ Edition). New York: Mc. Graw Hill Companies.

Irvan, I Putu dan Ni Luh Karmini. (2016). Pengaruh Pendapatan Asli Daerah, Dana Perimbangan Terhadap Pertumbuhan Ekonomi dengan Belanja Modal Sebagai Variabel Intervening. E-Jurnal EP Unud, 5(3), 338-362.

Oates, Wallace E. (1993). Fiscal Decentralization and Economic Development. National Tax Journal, 46(2), 237-243.

Rizky, R. L., Grisvia A., dan Imam M. (2016). Pengaruh Penanaman Modal Asing, Penanaman Modal Dalam Negeri, dan Belanja Modal Terhadap Pertumbuhan Ekonomi Provinsi di Indonesia. JESP, 8(1), 9-16.

Rofii, A. M. dan Putu S. A. (2017). Analisis Pengaruh Inflasi, Penanaman Modal Asing (PMA) dan Tenaga Kerja Terhadap Pertumbuhan Ekonomi di Jawa Timur. Jurnal Ekonomi dan Bisnis, 2(1), 303-316.

Sukirno, Sadono. (2005). Pengantar Makro Ekonomi. Jakarta: Raja Grafindo Persada.

Todaro, M.P dan Stephen C.S. (2003). Pembangunan Ekonomi di Dunia Ketiga Edisi Kedelapan : Jilid 1. Jakarta : Erlangga.

UU Nomor 25 Tahun 2007 tentang Penanaman Modal.

UU Nomor 33 Tahun 2004 tentang Perimbangan Keuangan Antara Pemerintah Pusat dan Pemerintah Daerah. 


\section{LAMPIRAN}

\section{Uji Chow}

Redundant Fixed Effects Tests

Equation: Untitled

Test cross-section fixed effects

\begin{tabular}{lrrr}
\hline \hline Effects Test & Statistic & d.f. & Prob. \\
\hline \hline Cross-section F & 368.592389 & $(34,136)$ & 0.0000 \\
Cross-section Chi-square & 793.483367 & 34 & 0.0000 \\
\hline \hline
\end{tabular}

\section{Uji LM}

\begin{tabular}{|c|c|c|c|}
\hline Statistik Uji & df & $\begin{array}{c}\text { Chi-Square } \\
\text { Tabel }\end{array}$ & Keputusan \\
\hline 87.38221 & 34 & 48,6024 & Tolak H0 \\
\hline \multicolumn{4}{|c|}{$\begin{array}{r}\text { Kesimpulan : Struktur matriks varians kovarian } \\
\text { residual bersifat heteroskedastis }(\alpha=5 \%)\end{array}$} \\
\hline
\end{tabular}

\section{Uji Normalitas}

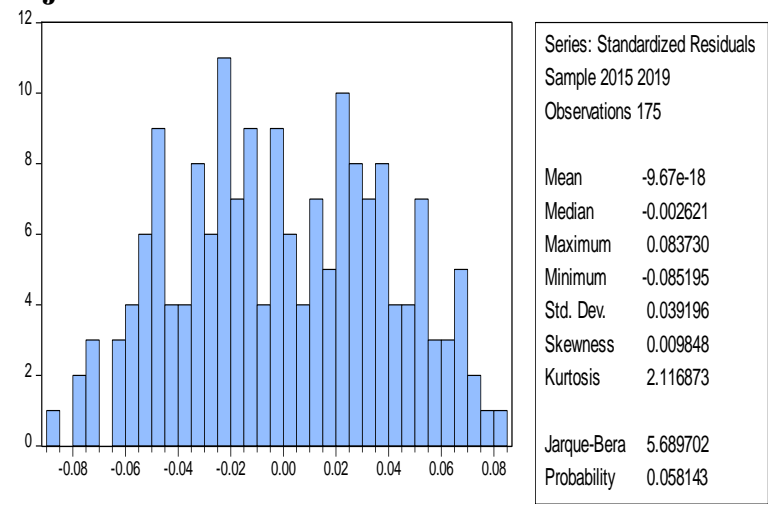

7. Efek Individu

\begin{tabular}{|c|l|c|}
\hline & \multicolumn{1}{|c|}{ Daerah } & Effect \\
\hline 1 & Kabupaten Cilacap & 1.240661 \\
\hline 2 & Kabupaten Banyumas & 0.232863 \\
\hline 3 & Kabupaten Purbalingga & -0.213163 \\
\hline 4 & Kabupaten Banjarnegara & -0.355566 \\
\hline 5 & Kabupaten Kebumen & -0.339916 \\
\hline 6 & Kabupaten Purworejo & -0.542355 \\
\hline 7 & Kabupaten Wonosobo & -0.382762 \\
\hline 8 & Kabupaten Magelang & -0.046371 \\
\hline 9 & Kabupaten Boyolali & -0.060252 \\
\hline 10 & Kabupaten Klaten & 0.049455 \\
\hline 11 & Kabupaten Sukoharjo & 0.183036 \\
\hline 12 & Kabupaten Wonogiri & -0.154824 \\
\hline 13 & Kabupaten Karanganyar & 0.131831 \\
\hline 14 & Kabupaten Sragen & 0.105233 \\
\hline 15 & Kabupaten Grobogan & -0.259743 \\
\hline 16 & Kabupaten Blora & -0.217516 \\
\hline 17 & Kabupaten Rembang & -0.38158 \\
\hline
\end{tabular}

\section{Uji Hausman}

Correlated Random Effects - Hausman Test

Equation: Untitled

Test cross-section random effects

\begin{tabular}{lrrr}
\hline \hline Test Summary & $\begin{array}{c}\text { Chi-Sq. } \\
\text { Statistic }\end{array}$ & Chi-Sq. d.f. & Prob. \\
\hline \hline Cross-section random & 28.401699 & 4 & 0.0000 \\
\hline \hline
\end{tabular}

\section{4. $\mathrm{Uji} \lambda L M$}

\begin{tabular}{|c|c|c|c|}
\hline Statistik Uji & df & $\begin{array}{c}\text { Chi-Square } \\
\text { Tabel }\end{array}$ & Keputusan \\
\hline 1557.767 & 595 & 652,8556 & Tolak H0 \\
\hline Kesimpulan : Terdapat cross sectional correlation \\
$(\alpha=5 \%)$
\end{tabular}

\section{Uji Nonmultikolinearitas}

\begin{tabular}{|c|c|c|c|}
\hline \multicolumn{4}{|c|}{$\begin{array}{l}\text { Variance Inflation Factors } \\
\text { Date: 01/21/21 Time: 11:24 } \\
\text { Sample: } 20152019 \\
\text { Included observations: } 175\end{array}$} \\
\hline Variable & $\begin{array}{l}\text { Coefficient } \\
\text { Variance }\end{array}$ & $\begin{array}{c}\text { Uncentered } \\
\text { VIF }\end{array}$ & $\begin{array}{c}\text { Centered } \\
\text { VIF }\end{array}$ \\
\hline C & 2.399325 & 49526.33 & NA \\
\hline LOG(PAD) & 0.001659 & 14277.61 & 1.229589 \\
\hline LOG(PERIMBANGAN) & 0.004639 & 41844.66 & 1.189873 \\
\hline LOG(PMDN) & $5.74 \mathrm{E}-07$ & 2.506311 & 1.078503 \\
\hline LOG(PMA) & $1.09 \mathrm{E}-06$ & 2.587862 & 1.279143 \\
\hline
\end{tabular}

\begin{tabular}{|r|l|r|}
\hline 18 & Kabupaten Pati & 0.118001 \\
\hline 19 & Kabupaten Kudus & 1.250362 \\
\hline 20 & Kabupaten Jepara & -0.114012 \\
\hline 21 & Kabupaten Demak & -0.216543 \\
\hline 22 & Kabupaten Semarang & 0.438013 \\
\hline 23 & Kabupaten Temanggung & -0.276211 \\
\hline 24 & Kabupaten Kendal & 0.303051 \\
\hline 25 & Kabupaten Batang & -0.231218 \\
\hline 26 & Kabupaten Pekalongan & -0.333414 \\
\hline 27 & Kabupaten Pemalang & -0.321653 \\
\hline 28 & Kabupaten Tegal & -0.037932 \\
\hline 29 & Kabupaten Brebes & 0.141555 \\
\hline 30 & Kota Magelang & -0.657063 \\
\hline 31 & Kota Surakarta & 0.535246 \\
\hline 32 & Kota Salatiga & -0.226555 \\
\hline 33 & Kota Semarang & 1.395364 \\
\hline 34 & Kota Pekalongan & -0.537552 \\
\hline 35 & Kota Tegal & -0.218471 \\
\hline
\end{tabular}

